\title{
Locally Advanced Urethral Urothelial
} Carcinoma

National Cancer Institute

\section{Source}

National Cancer Institute. Locally Advanced Urethral Urothelial Carcinoma. NCI

Thesaurus. Code C162619.

A urethral urothelial carcinoma that has spread from its original site of growth to nearby tissues or lymph nodes. 